Magdalena Perkowska

Uniwersytet w Biatymstoku

Emilia Jurgielewicz

Uniwersytet w Biatymstoku

\title{
ZWALCZANIE NIELEGALNEJ MIGRACJI W POLSKIM PRAWIE KARNYM. WYBRANE ASPEKTY IMPLEMENTACJI PRAWA UNII EUROPEJSKIEJ
}

\section{Wprowadzenie}

Jednym z fundamentalnych praw gwarantowanych przez Unię Europejską zarówno w prawie pierwotnym, jak i wtórnym jest swobodny przepływ osób ${ }^{1}$. Realizowane jest ono poprzez funkcjonujący na jej terenie obszar wolności, bezpieczeństwa i sprawiedliwości bez granic wewnętrznych. W związku ze zniesieniem kontroli na granicach pomiędzy państwami członkowskimi UE musiała wzmocnić system zarządzania granicami zewnętrznymi. Zaś poprzez wspólną politykę azylową i imigracyjną, zaczęto regulować napływ obywateli spoza UE oraz opracowywać zasady związane $\mathrm{z}$ ich zamieszkiwaniem na terenie UE.

$\mathrm{Z}$ przepływem osób nieodzownie związane jest zjawisko nielegalnej migracji, szczególnie niebezpieczne dla Polski ${ }^{2}$ ze względu na położenie geograficzne. Przez terytorium RP wiodą korytarze tranzytowe nielegalnej migracji ze wschodu na zachód oraz z południa na północ Europy.

\section{Regulacje UE w zakresie zwalczania nielegalnej migracji}

Przepis art. 79 ust. 1 TFUE $^{3}$ stanowi, iż celem polityki imigracyjnej jest zapewnienie właściwego zarządzania przepływami migracyjnymi, sprawiedliwego

\footnotetext{
$1 \quad$ Układ z Schengen z 1985 r. oraz Konwencja Wykonawcza do Układu z Schengen z 1990 r. pozwoliły zrealizować ideę swobodnego przepływu osób, co zapoczątkowało proces znoszenia kontroli granicznych między uczestniczącymi państwami.

2 Szerzej nt. nielegalnej migracji w Polsce: M. Perkowska, Fenomen nielegalnej migracji w Polsce, (w:) O. Łachacz, J. Galster (red.), Status cudzoziemca w prawie międzynarodowym. Implikacje w prawie Unii Europejskiej i polskim porządku prawnym, Olsztyn 2013, s. 305-318.

3 Traktat o funkcjonowaniu Unii Europejskiej, Dz.U. z 2004 r. Nr 90, poz. 864/2.
} 
traktowania obywateli państw trzecich, którzy legalnie przebywają w państwach członkowskich UE, zapobiegania i zwalczania nielegalnej imigracji oraz handlu ludźmi. Parlament Europejski i Rada w celu realizacji powyższego celu mogą podejmować działania wymienione w ust. 2. Pośród nich znajdują się środki dotyczące: warunków wjazdu i pobytu, procedur wydawania długoterminowych wiz oraz dokumentów pobytowych, określania praw obywateli państw trzecich przebywających legalnie na terenie UE, nielegalnej imigracji ${ }^{4} \mathrm{i}$ pobytu, zwalczania handlu ludźmi. Co więcej, art. 79 daje w ust. 3 kompetencję UE do zawierania umów readmisyjnych, dotyczących obywateli państw trzecich, niespełniających warunków wjazdu, obecności bądź pobytu na terytorium jednego z krajów należących do UE, tudzież przestali je spełniać, do państw pochodzenia lub państw, z których oni przybywają ${ }^{5}$. Art. 79 ust. 4 stanowi podstawę do ustanawiania programów na rzecz integracji obywateli państw trzecich przebywających legalnie w państwach członkowskich. $\mathrm{Z}$ kolei ust. 5 tego artykułu daje unijnym państwom kompetencję do wyznaczania limitów napływu cudzoziemców poszukujących w nich zatrudnienia.

Bardziej szczegółowe regulacje dotyczące zwalczania nielegalnej imigracji zawierają akty prawa wtórnego. W dyrektywie Rady 2002/90/WE ${ }^{6}$ zawarto istotną dla podjętych w opracowaniu rozważań definicję ułatwiania nielegalnego wjazdu, tranzytu i pobytu. Zgodnie z art. 1 dyrektywy nielegalną imigracją będzie:

- umyślne pomaganie osobie niebędącej obywatelem kraju członkowskiego UE we wjeździe lub tranzycie przez unijne terytorium poprzez naruszenie przepisów dotyczących wjazdu lub tranzytu cudzoziemców,

- umyślne pomaganie, któremu towarzyszy korzyść finansowa, osobie niebędącej obywatelem kraju członkowskiego UE w zamieszkaniu na terytorium UE z naruszeniem przepisów dotyczących pobytu cudzoziemców,

- podżeganie, współsprawstwo lub usiłowanie popełnienia jednego z wymienionych powyżej zachowań.

Wspólne działania państw UE podejmowane w ramach współpracy policyjnej i sądowej w sprawach karnych są niezbędne do budowania obszaru wolności, bezpieczeństwa i sprawiedliwości. Dlatego państwa członkowskie powinny podejmować m.in. środki pozwalające zapobiegać nielegalnym imigracjom. W tym celu decyzja ramowa w sprawie wzmocnienia systemu karnego w celu zapobiegania ułatwianiu nielegalnego wjazdu, tranzytu i pobytu ${ }^{7}$ ustanawia minimalne zasady doi polityki wybranych państw członkowskich, (w:) T. Jasudowicz, M. Balcerzak (red.), Księga pamiątkowa ku czci Profesora Jana Białocerkiewicza, Toruń 2009, s. 521-536.

$5 \quad$ K. Strąk, Komentarz do art. 79 TFUE, (w:) A. Wróbel, D. Miąsik, N. Półtorak (red.), Traktat o funkcjonowaniu Unii Europejskiej. Komentarz. Tom I (art. 1-89), Warszawa 2012, s. 1141.

6 Dyrektywa Rady 2002/90/WE z dn. 28 listopada 2002 r. definiująca ułatwianie nielegalnego wjazdu, tranzytu i pobytu, Dz.U. UE. L. z 2002 r., Nr 328, poz. 17.

7 Decyzja Ramowa Rady 2002/946/WSiSW z dn. 28 listopada 2002 r. w sprawie wzmocnienia systemu karnego w celu zapobiegania ułatwianiu nielegalnego wjazdu, tranzytu i pobyt, Dz.U. UE. L. z 2002 r., Nr 328, poz. 1. 
tyczące kar, odpowiedzialności osób prawnych oraz jurysdykcji. Zobowiązuje ona państwa członkowskie do nakładania skutecznych, proporcjonalnych i odstraszających sankcji, mogących pociągać za sobą nawet ekstradycję w celu zwalczania naruszeń opisanych powyżej z dyrektywy 2002/90/WE. Akt ten uprawnia państwa unijne do nakładania, obok kar, środków takich jak: konfiskata środka transportu użytego do popełnienia przestępstwa, zakaz wykonywania bezpośrednio lub poprzez pośrednika działalności zawodowej, podczas wykonywania której zostało popełnione przestępstwo czy też wydalenie. W sytuacji zaś, kiedy w celu osiągnięcia korzyści finansowej umyślnie udzielana jest pomoc osobie z państwa nienależącego do UE w nielegalnym wjeździe, tranzycie przez UE lub następuje podżeganie do popełnienia takiego działania ma być orzekana kara pozbawienia wolności z najwyższym wymiarem nie mniejszym niż 8 lat.

Unia Europejska regulując kwestie związane z nielegalną imigracją w dyrektywie Parlamentu Europejskiego i Rady 2009/52/WE ${ }^{8}$ przewidziała minimalne normy w odniesieniu do kar i środków stosowanych wobec pracodawców zatrudniających nielegalnie przebywających obywateli krajów trzecich. Art. 1 dyrektywy określa jej przedmiot i zakres stosowania tj. przeciwdziałanie nielegalnej imigracji, poprzez wprowadzenie zakazu zatrudniania nielegalnie przebywających obywateli krajów trzecich. Określa minimalne standardy, które dotyczą kar oraz środków, mających zastosowanie w państwach członkowskich wobec pracodawców naruszających ten zakaz. Nakładając na państwa członkowskie obowiązek wprowadzenia zakazu zatrudniania nielegalnie przebywających obywateli państw nienależących do UE, dyrektywa w art. 2 wyjaśnia istotne pojęcia związane z tym procederem:

- obywatelem kraju trzeciego jest każda osoba niebędąca obywatelem UE i niebędąca osobą korzystającą ze wspólnotowego prawa do swobodnego przemieszczania się,

- nielegalnie przebywającym obywatelem kraju trzeciego jest osoba, która nie spełnia lub przestała spełniać warunki pobytu lub zamieszkania w państwie członkowskim UE,

- nielegalne zatrudnianie polega na wykonywaniu działalności obejmującej wszelkie formy pracy, regulowane na mocy prawa krajowego lub zgodnie z ustaloną praktyką, na rzecz pracodawcy albo pod jego kierownictwem lub nadzorem przez nielegalnie przebywającego obywatela kraju trzeciego,

- warunkami szczególnego wyzysku są warunki pracy, wynikające z dyskryminacji ze względu na płeć lub z innego rodzaju dyskryminacji, w których występuje uderzająca dysproporcja w porównaniu z warunkami zatrudnienia pracowników zatrudnionych legalnie, co wpływa np. na zdrowie i bezpieczeństwo pracowników oraz uchybia godności ludzkiej, 
- wynagrodzeniem nielegalnie przebywających obywateli krajów trzecich jest płaca lub pensja oraz wszelkie inne świadczenia gotówkowe lub rzeczowe, otrzymywane przez pracownika bezpośrednio lub pośrednio w związku ze swoim zatrudnieniem od pracodawcy i które jest równorzędne $z$ tym, jakie otrzymywaliby porównywalni pracownicy w ramach legalnego stosunku pracy.

Zgodnie z art. 4 analizowanej dyrektywy pracodawcy zobowiązani są do tego, by wymagać od obywateli państw trzecich, zanim podejmą zatrudnienie, posiadania i przedstawienia ważnego zezwolenia na pobyt. Co więcej, mają oni przechowywać przynajmniej przez cały okres trwania zatrudnienia kopię albo odpis tego zezwolenia. Jest to niezbędne podczas ewentualnych kontroli ze strony właściwych organów. Pracodawcy mają także obowiązek powiadamiania właściwych organów wyznaczonych przez państwa członkowskie $\mathrm{w}$ terminie określonym przez każde z państw o rozpoczęciu zatrudnienia obywateli krajów trzecich. Warto też zwrócić uwagę, że w przypadku, gdy osoba fizyczna będąca pracodawcą zatrudnia obywatela kraju trzeciego na użytek prywatny, państwo członkowskie ma możliwość zastosowania uproszczonej procedury powiadamiania. Ponadto, obowiązek powiadamiania może zostać zniesiony wówczas, kiedy owemu pracownikowi przyznano status rezydenta długoterminowego.

Na mocy dyrektywy 2009/52/WE/WE państwa członkowskie UE mają dbać o to, by naruszenia związane z zatrudnianiem nielegalnie przebywających obywateli państw trzecich podlegały skutecznym, proporcjonalnym i odstraszającym karom, obejmującym (art. 5 ust. 1):

- kary finansowe, których wysokość uzależniona jest od liczby nielegalnie zatrudnionych obywateli krajów trzecich,

- pokrycie kosztów powrotu nielegalnie zatrudnionych obywateli krajów trzecich w tych przypadkach, gdy przeprowadzane są procedury powrotu.

Art. 7 ust. 1 dyrektywy przewiduje, że kraje należące do UE podejmą niezbędne działania służące zapewnieniu, iż w stosownych przypadkach wobec pracodawców znajdą zastosowanie takie środki, jak: pozbawienie uprawnienia do korzystania z niektórych lub wszystkich świadczeń publicznych, w tym funduszy UE na okres do 5 lat, wykluczenie $\mathrm{z}$ udziału w zamówieniach publicznych na okres do 5 lat, nakaz zwrotu świadczeń przyznanych pracodawcy w okresie do 12 miesięcy poprzedzających wykrycie nielegalnego zatrudnienia, czasowe lub trwałe zamknięcie zakładu.

Istotnym z punktu prowadzonych rozważań jest art. 9 dyrektywy, stanowiący, że państwa UE mają zapewnić, by naruszenie zakazu, polegające na umyślnym zatrudnianiu nielegalnie przebywających obywateli krajów trzecich uznawane było za przestępstwo, w przypadku gdy naruszenie to: 
- trwa lub jest uporczywie ponawiane,

- dotyczy jednoczesnego zatrudniania znaczącej liczby nielegalnie przebywających obywateli krajów trzecich,

- związane jest ze szczególnym wyzyskiem,

- związane jest z zatrudnianiem ofiar handlu ludźmi czy małoletnich.

Co więcej, zgodnie z art. 9 ust. 2 zarówno podżeganie do popełnienia tych czynów, jak i pomocnictwo w ich popełnieniu mają podlegać karze jako przestępstwo.

Solidarność, wzajemne zaufanie oraz współdziałanie państw członkowskich są podstawowymi warunkami funkcjonowania obszaru bez granic wewnętrznych. Niemniej jednak, ten największy ciężar w związku z nielegalną imigracją spada na te państwa członkowskie, które kontrolują granice zewnętrzne, m.in. Polskę. Dlatego, poniżej przeprowadzono rozważania dotyczące implementacji prawa unijnego związanego z przedmiotowym problem - do porządku prawnego Polski.

\section{Zwalczanie nielegalnej migracji w polskim prawie karnym}

Implementując decyzję ramową 2002/946/WSiSW oraz dyrektywę 2002/90/ WE, ustawodawca ${ }^{9}$ dokonał penalizacji podejmowania działań, w celu osiągnięcia korzyści majątkowej lub osobistej, polegających na bezprawnym umożliwianiu lub ułatwianiu innej osobie pobytu na terytorium RP (art. 264a § 1 k.k.) Zwiększono takżę ustawowe zagrożenie karą za przestępstwo określone w art. $264 \S 3$ k.k. (organizowanie nielegalnego przekraczania granicy) poprzez ustalenie jej wymiaru w granicach od 6 miesięcy do 8 lat pozbawienia wolności - zgodnie z wymaganiami art. 1 ust. 3 decyzji ramowej ${ }^{10}$. Art. 264a k.k. stanowi reakcję na, będący konsekwencją zwiększenia się atrakcyjności Polski dla imigrantów, ich wzmożony napływ i nielegalny pobyt. Często nie byłoby to możliwe bez zaangażowania się innych osób w jego umożliwienie lub ułatwianie. W przepisie przewidziano jednak możliwość zastosowania w wyjątkowych wypadkach nadzwyczajnego złagodzenia kary, a nawet odstąpienia od jej wymierzenia ${ }^{11}$.

W ocenie ustawodawcy nie w każdym przypadku popełnienia rzeczonego czynu przestępnego konieczne jest wymierzenie sprawcy kary przewidzianej w ustawowym zagrożeniu art. 264a $§ 1$ k.k. W wyjątkowych wypadkach, gdy sprawca nie

9 Uzasadnienie do zmiany ustawy - Kodeks karny oraz niektórych innych ustaw, Sejm RP IV kadencji. Nr druku: 2407, s. 14.

10 Uzasadnienie do zmiany ustawy - Kodeks karny..., op. cit.; W. Grzeszczyk, Zmiany w prawie karnym wprowadzone ustawą z dn. 16 kwietnia 2004 r., Prok. i Pr. 2004, nr 9, s. 74-76. Szerzej nt. dekryminalizacji nielegalnego przekroczenia granicy M. Perkowska, Prawne i kryminologiczne aspekty dekryminalizacji przestępstwa nielegalnego przekroczenia granicy, (w:) S. Pikulski, M. Romańczuk-Grącka (red.), Granice kryminalizacji i penalizacji, Olsztyn 2013, s. 505-515.

11 Z. Ćwiąkalski, (w:) A. Zoll, Kodeks karny. Część szczególna, Tom II. Komentarz do art. 117-277 kk., Warszawa 2013, s. 1454. 
osiągnął korzyści majątkowej, sąd może na podstawie art. 264a § 2 k.k. zastosować wobec sprawcy nadzwyczajne złagodzenie, a nawet odstąpić od wymierzenia kary ${ }^{12}$.

$\mathrm{W} \S 1$ ujęto typ podstawowy przestępstwa, będący niejako rozwinięciem przepisu art. 264 § 2 i 3 k.k. W przepisie art. 264 k.k. mowa jest bowiem o nielegalnym przekroczeniu granicy RP oraz o organizowaniu takiego przekraczania, zaś w art. 264a k.k. przestępstwem jest nielegalny pobyt już na terenie RP. Według E.W. Pływaczewskiego przedmiotem bezpośrednim ochrony art. 264a k.k. jest ochrona granicy państwowej ${ }^{13}$ przed przekroczeniem jej w sposób niezgodny z prawem, zaś pośrednim - bezpieczeństwo państwa ${ }^{14}$.

Czynność sprawcza polega na „umożliwianiu” lub ,ułatwianiu” innej osobie pobytu na terytorium Rzeczypospolitej Polskiej wbrew przepisom. Słowo „umożliwianie" należy rozumieć jako stwarzanie warunków sprzyjających czemuś, przyczynienie się do czegoś. W rezultacie chodzi o stworzenie przez sprawcę warunków innej osobie, umożliwiających jej nielegalny pobyt na terytorium RP. Zachowanie sprawcy może również przyczynić się do tego, że ta inna osoba pozostanie w Polsce nielegalnie. Określenie „ułatwianie” należy rozumieć jako dopomożenie w osiąganiu czegoś. W tym przypadku dopomożenie polega na tym, że danej osobie udaje się przebywać nielegalnie w Polsce ${ }^{15}$.

Umożliwienie i ułatwienie są $\mathrm{w}$ istocie formami pomocnictwa do przebywania na terytorium RP. Przestępstwo to może być popełnione z działania lub z zaniecha$n^{16}{ }^{16}$. Umożliwienie to „sprawienie warunków, że coś staje się możliwe, stworzenie warunków sprzyjających czemuś, przyczynienie się do czegoś”. Dzięki tym zachowaniom pobyt cudzoziemca jest w ogóle możliwy. Z punktu widzenia językowego ułatwienie polega na „sprawieniu, że coś staje się prostsze, łatwiejsze”. Ułatwienie ogranicza się do zachowań, które powodują, że pozostawanie na terytorium RP jest prostsze ${ }^{17}$. Ułatwienie może polegać na ukrywaniu osoby nielegalnie przebywającej na terytorium RP lub wynajęcie jej mieszkania. W doktrynie słusznie wskazuje się, że ułatwieniem pobytu jest udzielenie jednego noclegu ${ }^{18}$.

Kryminalizacji poddane jest opisane $\mathrm{w}$ przepisie zachowanie podejmowane w stosunku do osoby, która ma zamiar przebywać lub przebywa na terytorium RP „wbrew przepisom”, a więc do osoby, która chce pozostawać na terytorium RP bez tytułu prawnego. Osobą tą może być tylko cudzoziemiec. Cudzoziemcem zaś jest każdy, kto nie posiada obywatelstwa polskiego ${ }^{19}$. Wprawdzie w art. 264a § 1 k.k. nie

\footnotetext{
12 P. Gensikowski, Odstąpienie od wymierzenia kary w polskim prawie karnym, Warszawa 2011, s. 182 i n.

13 E. Pływaczewski, (w:) M. Filar (red.), Kodeks karny. Komentarz, Warszawa 2012, s. 1197.

14 E. Pływaczewski, A. Sakowicz (w:) A. Wąsek, R. Zawłocki (red.), Kodeks karny, część szczególna. Tom II. Komentarz do artykułów 222-316, Warszawa 2010, s. 534.

15 Z. Ćwiąkalski, op. cit. s. 1455.

16 O. Górniok, (w:) O. Górniok, S. Hoc, M. Kalitkowski, S.M. Przyjemski, Z. Sienkiewicz, J. Szumski, L. Tyszkiewicz,

A. Wasek, Kodeks karny. Komentarz, Tom II, Art. 117-363, Warszawa 2005, s. 354.

17 R.A. Stafański, op. cit., s. 17 i cytowana tam literatura.

18 O. Górniok, op. cit.

19 Na podstawie art. 2 ustawy z dn. 13 czerwca 2003 r. o cudzoziemcach, Dz.U. Nr 128, poz. 1175.
} 
wskazano expresis verbis, iż przepis dotyczy cudzoziemca, lecz wynika to z ustawy o cudzoziemcach, która określa zasady i warunki pobytu cudzoziemców na terytorium $\mathrm{RP}^{20}$.

W literaturze pojęcie „wbrew przepisom” ogranicza się niesłusznie do zakazu pobytu, dodając, że może ono polegać na nakazie zobowiązującym określoną osobę do uzyskania zezwolenia na pobyt w Polsce ${ }^{21}$. Chodzi o umożliwienie lub ułatwienie cudzoziemcowi pobytu wbrew obowiązującym przepisom, a nie pomoc w uzyskaniu legalnego pobytu.

Jest to przestępstwo formalne. Ponadto dla jego bytu nie jest wymagane osiągnięcie korzyści majątkowej lub osobistej ${ }^{22}$. Przy czym, jeśli sprawca nie osiągnął korzyści majątkowej, sąd może bowiem na podstawie art. 264a $§ 2$ k.k. zastosować wobec sprawcy nadzwyczajne złagodzenie, a nawet odstąpić od wymierzenia kary ${ }^{23}$.

Zakres znaczeniowy wyrażenia ,wyjątkowy wypadek” użytego przez ustawodawcę w art. 264a $\S 2$ k.k. nie jest jasny. Nasuwa się w szczególności pytanie: czy przytoczone sformułowanie obejmuje również sytuacje faktyczne, gdy sprawca osiągnął z popełnionego przestępstwa korzyść osobistą? Verba legis analizowany przepis odwołuje się jedynie do braku osiągnięcia przez sprawcę korzyści majątkowej. Wydaje się zatem, że katalog sytuacji uznanych przez ustawodawcę za ,wyjątkowe wypadki” w rozumieniu art. 264a $\S 2$ k.k. obejmuje także przypadek sprawcy, który osiągnął z czynu zabronionego określonego w art. 264a $\S 1$ k.k. jedynie korzyść osobistą ${ }^{24}$.

Kolejnym wyrazem implementacji prawa UE, a właściwie dyrektywy 2009/52/ WE, w zakresie zwalczania nielegalnej migracji jest ustawa o skutkach powierzania wykonywania pracy cudzoziemcom przebywającym wbrew przepisom na terytorium Rzeczypospolitej Polskiej ${ }^{25}$.

Dyrektywa 2009/52/WE wprowadza zakaz zatrudniania obywateli państw trzecich nielegalnie przebywających na terytorium państw członkowskich ${ }^{26}$. Pojęcie cudzoziemca zostało zawężone w ustawie, zgodnie z dyrektywą 2009/52/WE27, w porównaniu do ogólnej definicji zawartej w art. 2 ustawy o cudzoziemcach. Ustawa o cudzoziemcach (jak i ustawa o promocji zatrudnienia - art. 2 ust. 1 pkt 7) określa, iż cudzoziemcem jest każda osoba, która nie posiada obywatelstwa polskiego.

\footnotetext{
20 R.A. Stafański, Przestępstwo umożliwienia lub ułatwienia nielegalnego pobytu (art. 264a kk.), Prok. i Pr. 2005, nr 11, s. 8.

A. Marek, Kodeks karny. Komentarz, Warszawa 2005, s. 549.

E. Pływaczewski, A. Sakowicz, op. cit., s. 535-536.

P. Gensikowski, op. cit.

Ibidem.

Ustawa z dn. 15 czerwca 2012 r. o skutkach powierzania wykonywania pracy cudzoziemcom przebywającym wbrew przepisom na terytorium Rzeczypospolitej Polskiej, Dz.U. 2012, poz. 769. Dalej jako: ustawa.

26 Szerzej nt. statystyki nielegalnego zatrudnienia cudzoziemców w Polsce: Państwowa Inspekcja Pracy, Kontrole legalności zatrudnienia, w tym zatrudnienia obcokrajowców, Warszawa 2013, s. 40. 
Ustawa ponadto przewiduje sankcje karne i administracyjne dla pracodawców naruszających ten zakaz, w tym także odpowiedzialność osób prawnych, a w określonych przypadkach także odpowiedzialność finansową wykonawcy za naruszenie obowiązków pracodawcy przez podwykonawcę.

Ogólne warunki legalnego zatrudnienia cudzoziemca w Polsce określają: ustawa o promocji zatrudnienia i instytucjach rynku pracy ${ }^{28}$ oraz analizowana ustawa.

W prawie polskim implementacja dyrektywy 2009/52/WE wprowadziła zaostrzenie odpowiedzialności za nielegalne zatrudnienie cudzoziemców. Ustawa w art. 2 nakłada na pracodawcę obowiązek żądania od cudzoziemca przedstawienia przed rozpoczęciem pracy ważnego dokumentu uprawniającego do pobytu na terytorium Polski ${ }^{29}$.

Ustawa o promocji zatrudnienia penalizuje $\mathrm{w}$ art. 120 nielegalne zatrudnienie cudzoziemców. Jest to wykroczenie polegające na powierzeniu cudzoziemcowi nielegalnego wykonywania pracy zagrożone karą grzywny do $3000 \mathrm{zl}$. Zgodnie $\mathrm{z}$ treścią art. 2 ust. 2 ustawy o promocji zatrudnienia karze podlega również cudzoziemiec nielegalnie wykonujący pracę, $w$ tym przypadku jednak zagrożenie karą jest niższe, gdyż sięga maksymalnie $1000 \mathrm{zł}$. Zaostrzenie odpowiedzialności zatem polegało na wprowadzeniu dwóch nowych typów przestępstw oraz typu kwalifikowanego wykroczenia.

Przestępstwem zagrożonym karą grzywny lub karą ograniczenia wolności jest powierzenie, w tym samym czasie wykonywania pracy wielu cudzoziemcom przebywającym bez ważnego dokumentu uprawniającego do pobytu na terytorium RP lub powierzenie wykonywania pracy małoletniemu cudzoziemcowi przebywającemu bez ważnego dokumentu uprawniającego do pobytu na terytorium RP. Identyczną karą zagrożone jest zachowanie polegające na uporczywym powierzaniu wykonywania pracy cudzoziemcowi przebywającemu bez ważnego dokumentu uprawniającego do pobytu na terytorium RP, pod warunkiem, że działanie sprawcy realizowane jest w związku z wykonywaną działalnością gospodarczą.

Ustawodawca zaostrzył zatem odpowiedzialność za wykroczenie z art. $120 \S 1$ ustawy o promocji zatrudnienia kryminalizując w art. 9 ustawy jako występki. Wydawałoby się, że w tym przypadku mamy do czynienia z czynami przepołowionymi. Niemniej jednak strona przedmiotowa nie jest identyczna, gdyż w przypadku wykroczenia ustawodawca posłużył się określeniem „nielegalnego wykonywania pracy”, a w przypadku przestępstwa czynność sprawcza polega na ,powierzeniu, w tym samym czasie wykonywania pracy wielu cudzoziemcom przebywającym bez ważnego dokumentu uprawniającego do pobytu na terytorium RP”. Nielegalne wykonywanie pracy jest jednak terminem szerszym, obejmującym zarówno ,powierzenie, w tym samym czasie wykonywania pracy wielu cudzoziemcom przebywającym bez waż- 
nego dokumentu uprawniającego do pobytu na terytorium RP”, jak i inne przypadki np. legalny pobyt, ale bez zezwolenia na pracę.

W ustawie, z wyjątkiem jej tytułu, używane jest sformułowanie ,„przebywanie bez ważnego dokumentu uprawniającego do pobytu na terytorium RP” zamiast pierwotnie proponowanego w założeniach ,przebywanie wbrew przepisom”. Wynika to $\mathrm{z}$ konieczności precyzyjnego wskazania zakresu odpowiedzialności podmiotu powierzającego wykonywanie pracy cudzoziemcowi i wykluczenia odpowiedzialności w sytuacji zaprzestania spełniania przez cudzoziemca warunków pobytu lub zamieszkania, przy jednoczesnym posiadaniu przez cudzoziemca wciąż ważnego dokumentu. Podmiot powierzający wykonywanie pracy cudzoziemcowi może bowiem nie zdawać sobie sprawy z zaistnienia takich okoliczności, nie może być zatem karany w takiej sytuacji. Ponadto, art. 4 ust. 3 dyrektywy 2009/52/WE wyraźnie przewiduje brak odpowiedzialności pracodawcy za zatrudnienie nielegalnie przebywającego cudzoziemca, gdy dokonał on sprawdzenia posiadania przez cudzoziemca dokumentu uprawniającego do pobytu, przechowywania kopii takiego dokumentu przez cały okres zatrudnienia oraz powiadomienia właściwego organu o rozpoczęciu zatrudniania tego cudzoziemca ${ }^{30}$.

W art. 9 posłużono się nieostrym określeniem ,powierzenie wykonywania pracy wielu cudzoziemcom", problematyczne jest zatem ustalenie ilu cudzoziemców stanowi ,wielu”. Pomocne w tym zakresie może być stanowisko doktryny wypracowane na gruncie art. 140 k.k. czy 163 k.k.

Zdaniem Z. Ćwiąkalskiego, kiedy mowa w ustawie o ,wielu osobach”, należy to określenie interpretować jako „kilka”, a więc co najmniej 3 osoby ${ }^{31}$. Inni uważają, że wyraz ,wielu” musi oznaczać kilkanaście, co najmniej $10^{32}$. Ten ostatni pogląd trudno uznać za trafny. O ile słowo „kilka” jest liczebnikiem nieokreślonym, oznaczającym kilka pojedynczych osób (przedmiotów itp.), o tyle wyraz „wielu” oznacza jedynie „dużo, dużą ilość”, a nie jakiś liczebnik. Według A. Marka „wiele” jest pojęciem ocennym, oznaczającym „dużo, dużą ilość lub liczbę”, chodzi zatem o więcej niż kilka osób ${ }^{33}$ (według K. Buchały przyjęto uważać, że ,wielu” to ponad 5 osób $^{34}$ ). Ten tok rozumowania przyjął SA w Katowicach uznając, że skoro w konkretnym wypadku zagrożone było życie lub zdrowie siedmiorga małoletnich dzieci, wystarczy to do stwierdzenia, że niebezpieczeństwem objętych było wiele osób, co uzasadnia zastosowanie art. $163 \S 1$ k.k. ${ }^{35}$ Jest to rozstrzygnięcie oczywiście słuszne,

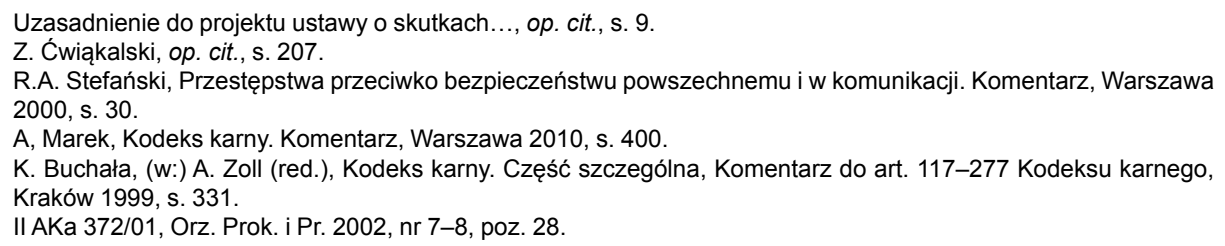


zdaniem G. Bogdana, który podziela pogląd, że w wypadku pojęć ocennych przewagę nad argumentami gramatycznymi winna mieć wykładnia celowościowa ${ }^{36}$.

Podobnie w art. 10 użyto zwrotu „w warunkach szczególnego wykorzystania” w przypadku powierzenia cudzoziemcowi przebywającemu bez ważnego dokumentu uprawniającego do pobytu na terytorium RP, tj. czynu stanowiącego występek zagrożony karą pozbawienia wolności do lat 3 . Jednak w tym przypadku w art. 10 ust. 3 ustawodawca wyjaśnił, iż chodzi tu o warunki pracy uchybiające godności człowieka i rażąco odmienne, w szczególności ze względu na płeć, w porównaniu $\mathrm{z}$ warunkami pracy osób, którym powierzono wykonywanie pracy zgodnie z prawem, wpływające zwłaszcza na zdrowie lub bezpieczeństwo osób wykonujących pracę. Wprowadzenie takiej regulacji jest istotne, gdyż nielegalnie zatrudniony cudzoziemiec jest narażony na łamanie nie tylko podstawowych jego praw pracowniczych, ale również i podstawowych praw człowieka ${ }^{37}$.

$\mathrm{W}$ art. 10 ustawy penalizuje również powierzenie pracy wbrew przepisom ustawy cudzoziemcowi, który jest pokrzywdzony przestępstwem określonym w art. $189 \mathrm{a} \S 1$ k.k.

W art. 11 ustawy wprowadzono typ kwalifikowany wykroczenia $\mathrm{z}$ art. 120 ustawy o promocji zatrudnienia polegający na uporczywym powierzaniu pracy cudzoziemcowi przebywającemu bez ważnego dokumentu uprawniającego do pobytu na terytorium RP, ale w okolicznościach, gdy praca nie ma związku z prowadzoną przez powierzającego działalnością gospodarczą. W przypadku tej regulacji posłużono się kolejnym nieostrym sformułowaniem, jakim jest określenie „uporczywie”.

Interpretacja tego pojęcia jest w literaturze sporna. Część doktryny uważa, że o uporczywości decyduje jedynie czynnik obiektywny - wielokrotność, powtarzalność zachowania się sprawcy. Większość doktryny opowiada się jednak za obiektywno-subiektywną interpretacją tego pojęcia. Do tego stanowiska, zdaniem M. Szewczyk, należy się przyłączyćc ${ }^{38}$. Jej zdaniem ,uporczywość” zachodzi w sytuacji powtarzającego się uchylania zabarwionego ujemnie $\mathrm{z}$ uwagi na złą wolę sprawcy. Na podstawie stanowiska $\mathrm{SN}^{39}$ można przyjąć, że „uporczywość” oznacza, że musi wystąpić wielokrotność zachowań na przestrzeni pewnego czasu, a ponadto znamię to wyraża psychiczne nastawienie sprawcy, który uchyla się od nałożonego na niego obowiązku pomimo realnej możliwości jego spełnienia; „uporczywość” jest antynomią jednorazowego czy nawet kilkakrotnego zachowania sprawcy.

G. Bogdan, (w:) A. Zoll, Kodeks karny. Część szczególna, Tom II. Komentarz do art. 117-277 kk., Warszawa 2006, s. 407.

M. Duszczyk, Imigrant - pracownik. Przestrzeganie praw pracowniczych i potencjalne problemy na rynku pracy, (w:) P. Dąbrowski, M. Duszczyk (red.), Przestrzeganie praw cudzoziemców w Polsce, „Biuletyn Rzecznika Praw Obywatelskich w Polsce" 2012, nr 11, s. 32.

M. Szewczyk, (w:) A. Zoll, Kodeks karny. Część szczególna, Tom II. Komentarz do art. 117-277 kk., Warszawa 2013, s. 909; A. Marek, op. cit., s. 476-477; Z. Siwik, (w:) M. Filar (red.), Kodeks karny. Komentarz, Warszawa 2012, s. 1049. V KKN 504/2000, OSNKW 2001, Nr 7-8, poz. 57. 
Przejawem zaostrzenia odpowiedzialności karnej wobec pracodawców nielegalnie zatrudniających cudzoziemców jest również wprowadzona do art. 12 ustawy możliwość orzeczenia wobec sprawców czynów określonych w art. 9 i 10 ustawy zakaz dostępu do środków pochodzących z funduszy strukturalnych, Funduszu Spójności i Europejskiego Funduszu Rybackiego, środków na realizację Wspólnej Polityki Rolnej oraz obowiązek zwrotu wymienionych środków otrzymanych w okresie 12 miesięcy poprzedzających wydanie wyroku. Są to sankcje zbieżne z tymi, które można stosować wobec podmiotu zbiorowego, zgodnie z art. 9 ustawy o odpowiedzialności podmiotów zbiorowych ${ }^{40}$.

\section{Wnioski}

Przedstawione w artykule zmiany dokonane w polskim prawie karnym w zakresie zwalczania nielegalnej migracji należy ocenić pozytywnie. Wychodząc od dekryminalizacji nielegalnego przekroczenia granicy, które to zachowanie zostało uznane za wykroczenie, a nie występek ${ }^{41}$. Poprzez kryminalizację zachowania polegającego na umożliwianiu lub ułatwianiu pobytu na terytorium RP wbrew przepisom i zaostrzenie odpowiedzialności za organizowanie nielegalnego przekroczenia granicy.

Podobnie należy ocenić zmiany dokonane ustawą o skutkach powierzania wykonywania pracy cudzoziemcom przebywającym wbrew przepisom na terytorium RP, szczególnie w zakresie zaostrzenia odpowiedzialności karnej, jaką wprowadziła przedmiotowa ustawa.

Negatywnie należy jednak ocenić sposób dokonania zmian - szczególnie uchwalenie nowej ustawy, tj. ustawy o skutkach powierzania wykonywania pracy cudzoziemcom przebywającym wbrew przepisom na terytorium RP. Powoduje to, że w zakresie ustalenia zasad odpowiedzialności karnej za nielegalne zatrudnienie cudzoziemców należy odnieść się do przepisów Kodeksu karnego, ustawy o promocji zatrudnienia, kodeksu wykroczeń oraz ustawy o skutkach powierzania wykonywania pracy cudzoziemcom przebywającym wbrew przepisom na terytorium RP.

Wymienione akty prawne stanowią kompleksowy zbiór przepisów prawnych w zakresie zwalczania nielegalnej migracji i nielegalnego zatrudnienia cudzoziemców. Błędnym jest jednak uchwalenie odrębnego aktu prawnego, zawierającego przepisy stanowiące zaostrzenie odpowiedzialności karnej ustanowionej zarówno w ustawie o promocji zatrudnienia, jak i kodeksie karnym. Rozsądniejszym rozwiązaniem byłoby wprowadzenie zmian do wskazanych ustaw.

\footnotetext{
40 Ustawa z dn. 28.10.2002 r. o odpowiedzialności podmiotów zbiorowych za czyny zabronione pod groźbą kary, Dz.U. 2002 Nr 197, poz. 1661.

41 Por. M. Perkowska, Prawne i kryminologiczne aspekty dekryminalizacji..., op. cit.
} 


\section{PREVENTING ILLEGAL IMMIGRATION IN CRIMINAL LAW - SELECTED ASPECTS OF IMPLEMENTATION OF EUROPEAN UNION REGULATIONS}

The article aims to present the implementation of three EU regulations concerning illegal immigration in Polish criminal law. Those regulations are: Council framework decision of 28 November 2002 on the strengthening of the penal framework to prevent the facilitation of unauthorised entry, transit and residence 2002/946/JHA; Council Directive 2002/90/EC defining the facilitation of unauthorised entry, transit and residence; Directive 2009/52/WE/EC of the European Parliament and of the Council providing for minimum standards on sanctions and measures against employers of illegally staying third-country nationals. The authors present new regulations in the field of penal law as article 264a of the Polish Criminal Code and law on the consequences of employing illegally staying third-country nationals from $15^{\text {th }}$ of June 2012.

Keywords: illegal immigration, unauthorised entry, illegal employment, foreigners 